\title{
Plasmid-determined Fusidic Acid Resistance in the Enterobacteriaceae
}

\author{
By NAOMI DATTA AND R. W. HEDGES \\ Bacteriology Department, Royal Postgraduate Medical School, London W12 OHS \\ AND DORIS BECKER AND J. DAVIES \\ Departments of Bacteriology and Biochemistry, College of Agricultural and Life Sciences, \\ University of Wisconsin-Madison, Madison, Wisconsin 53706, U.S.A.
}

(Received 6 March 1974)

\section{SUMMARY}

A number of $\mathrm{R}$ factors have been shown to determine resistance to fusidic acid, an antibiotic effective against Gram-positive bacteria. Among several $\mathrm{R}$ factors examined for this property only one was $\mathrm{fi}^{-}$; the remainder were $\mathrm{fi}^{+}$and of the FII compatibility group.

\section{INTRODUCTION}

Fusidic acid is a steroidal antibiotic which has been used in the treatment of staphylococcal infections, especially when penicillin resistance is a problem (Garrod, Lambert \& O'Grady, 1973). Reports of fusidic acid resistance among clinical isolates of Gram-positive organisms are rare. In two cases resistance seemed to be determined by plasmids in Staphy/ococcus aureus (Evans \& Waterworth, 1966).

Fusidic acid has no therapeutic application for Gram-negative bacteria because they are insensitive to the drug at concentrations attainable in body fluids. However, fusidic acid is a useful inhibitor of protein synthesis in bacteria and it has been studied extensively in appropriate strains of Escherichia coli. Mutants resistant to high concentrations, have been isolated and shown to have an altered translocation factor $\left(E F_{t:}\right)$; the drug interferes with the binding of aminoacyl-tRNA to ribosomes and is useful in studies of certain complexes involved in protein synthesis (Pestka, 1971; Cundliffe, 1972; Davies \& Nomura, 1972). E. coli mutants more than usually sensitive to fusidic acid have been isolated, and we presume that these mutants have altered cell envelopes, since they are also permeable to other agents which do not normally affect E. coli (Ennis, 197I; D. Becker and J. Davies, unpublished).

Since fusidic acid resistance is believed to be plasmid-determined in $S$. aureus, we tested whether any $\mathbf{R}$ factors of Enterobacteriaceae carried a fusidic acid-resistance determinant by transferring a variety of $\mathrm{R}$ factors into fusidic acid-sensitive mutants of $E$. coli and screening for resistance to the drug.

\section{METHODS}

Preparation of fusidic acid-sensitive strains of E. coli. E. coli $\mathrm{PR} 7 \mathrm{~F}^{-}$thi leu rits pap nal-r (Taylor, 1970) was grown to exponential phase in yeast extract-tryptone medium (ML) and treated with $100 \mu \mathrm{g} N$-methyl- $N^{\prime}$-nitro- $N$-nitrosoguanidine $/ \mathrm{ml}$ at $37{ }^{\circ} \mathrm{C}$ for $5 \mathrm{~min}$. The cells were collected by centrifuging, washed with ML medium, resuspended in the same medium and streaked on ML-agar plates. Colonies were picked on to ML plates with sterile toothpicks 
and replica-plated to a series of ML plates containing $(\mu \mathrm{g} / \mathrm{ml})$ : fusidic acid, Ioo; streptolydigin, I00; novobiocin, I00; clindamycin, 100. Strains sensitive to these antibiotics were isolated, purified and checked for auxotrophic markers. Most of the fusidic acid-sensitive mutants were also sensitive to the other drugs tested. E. coli DB IO is one such strain; a disc of fusidic acid $(20 \mu \mathrm{g})$ gave a zone of inhibition of $\mathrm{I} 8 \mathrm{~mm}$ on ML plates.

Transfer of fusidic acid resistance. $\mathrm{R}$ factor-containing strains and the recipient $E$. coli DB IO were grown to mid-exponential phase in ML broth and equal volumes were mixed and allowed to stand at $37^{\circ} \mathrm{C}$ for I $\mathrm{h}$. The mixed culture was streaked on ML plates containing nalidixic acid $(30 \mu \mathrm{g} / \mathrm{ml})$ and one of the antibiotics [usually neomycin $(20 \mu \mathrm{g} / \mathrm{ml})$ or kanamycin $(30 \mu \mathrm{g} / \mathrm{ml})$ ] to which the $\mathrm{R}$ factor conferred resistance. After incubation for $24 \mathrm{~h}$, colonies were picked and checked for nutritional and resistance markers. Resistance patterns were scored by disc tests; a disc of fusidic acid $(20 \mu \mathrm{g})$ gave a zone of inhibition of 17 to $19 \mathrm{~mm}$ on a sensitive strain, 8 to $10 \mathrm{~mm}$ on a resistance strain. No $\mathrm{R}$ factor-determined resistance to streptolydigin, novobiocin or clindamycin was detected. Fusidic acid resistance in mutant or wild-type $E$. coli KI 2 was also demonstrated using agar ditches containing various concentrations of fusidic acid.

Compatibility properties. These were determined by the techniques described by Datta et al. (1971) and Coetzee, Datta \& Hedges (1972).

Bacterial strains. $\mathrm{F}^{-}$E. coli KI2 strains, PR7 and its variant DBIO (described above), $\mathrm{J} 53$ pro met, $\mathrm{J} 53.2$ (a rifampicin-resistant mutant of $\mathrm{J} 53$ ), and $\mathrm{J} 62$ pro his trp lac, were used.

Plasmids. These are listed in Table $\mathrm{I}$. The isolation of plasmids lacking one or more resistance markers was as described by Coetzee et al. 1972.

\section{RESULTS}

Of ten different $R$ factors routinely screened at the start of the work, JR70, JR72 and JR73 conferred fusidic acid resistance. All three were $\mathrm{fi}^{+}$. All eliminated $\mathrm{R}_{\mathrm{I}-\mathrm{I}}$ efficiently when transferred into a strain carrying that plasmid.

JR73 was efficiently eliminated when R I-I was transferred into a JR $73^{+}$strain (20 of 20 transconjugants had lost resistance to kanamycin and tetracycline) and was thus a typical FII plasmid; JR70 was also eliminated by transfer of $\mathrm{R}_{\mathrm{I}-\mathrm{I}}$ but the elimination was less efficient, only two of 20 transconjugants had lost JR 70 resistances in the usual test screening but the doubles were unstable. When the doubles were grown in antibiotic-free medium, segregants lacking either one of the plasmids were observed, though $\mathrm{RI}^{-} \mathrm{I}^{-}$segregants were more abundant than $\mathrm{JR}_{70^{-}}$.

This pattern resembles the relationship observed by MacFarren \& Clowes (1967) between the $\mathrm{F}$ factor and $\mathrm{ColV}^{+}$factors. They found that transfer of an $\mathrm{F}$ factor into a $\mathrm{ColV}^{+}$strain efficiently eliminated the resident plasmid but that the reciprocal transfer led to elimination of the $\mathrm{F}$ factor only after long delay.

JR72 behaved differently. When RI-I was transferred into a strain carrying JR72, no transconjugants lacking the resident plasmid were observed (Table 2). The transconjugants

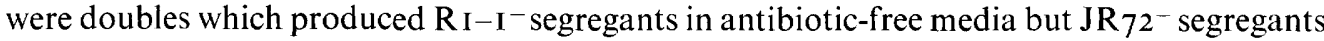
were never observed. When such an unstable double was transferred to nutrient broth containing $1000 \mu \mathrm{g}$ ampicillin/ml (an antibiotic to which $\mathrm{R}_{\mathrm{I}-\mathrm{I}}$, but not $\mathrm{JR}_{72}$, determines resistance) and incubated overnight, all the viable progeny tested ( 242 of 242 ) retained kanamycin resistance (a marker of JR72). 
Table 1. Plasmids used in this work

Abbreviations: A, ampicillin; S, streptomycin; T, tetracycline; C, chloramphenicol; K, kanamycin; Su, sulphonamide; Tp, trimethoprim; Gk, gentamicin/kanamycin.

\begin{tabular}{|c|c|c|c|c|}
\hline Designation & Properties & Resistances & Compatibility & Source or reference \\
\hline JR $70^{*}$ & + & $\mathrm{S}, \mathrm{T}, \mathrm{C}, \mathrm{K}, \mathrm{Su}$ & FII & E. coli JR 35 \\
\hline $\mathrm{JR} 72^{*}$ & + & $\mathrm{S}, \mathrm{C}, \mathrm{K}, \mathrm{Su}$ & FJJ & E. coli NIHJ 268 \\
\hline JR73* & + & $\mathrm{S}, \mathrm{T}, \mathrm{C}, \mathrm{K}, \mathrm{Su}$ & FII & \\
\hline $\mathrm{RI}-\mathrm{I}^{*}$ & + & $\mathrm{A}, \mathrm{S}, \mathrm{C}, \mathrm{Su}$ & FII & Hedges \& Datta (1972) \\
\hline $\mathrm{R} 28^{*}$ & + & $\mathrm{S}, \mathrm{T}, \mathrm{Su}$ & FII & $\begin{array}{l}\text { Lawn, Meynell, Meynell \& } \\
\text { Datta ( } 1967)\end{array}$ \\
\hline$R 136$ & + & $\mathrm{T}$ & FII & Lawnet al. (1967) \\
\hline $222^{*}$ & + & $\mathrm{S}, \mathrm{T}, \mathrm{C}, \mathrm{Su}$ & FII & Watanabe et al. (1964) \\
\hline R494 & + & $\mathrm{A}, \mathrm{T}, \mathrm{K}$ & FII & Hedges, unpublished \\
\hline Flac & $(-)$ & & $\mathrm{FI}$ & Dennison $(1972)$ \\
\hline $\mathrm{R}_{386}$ & + & $\mathrm{T}$ & $\mathrm{FI}$ & Dennison (1972) \\
\hline $\mathrm{R}_{455}$ & + & $\mathrm{A}, \mathrm{S}, \mathrm{T}, \mathrm{C}, \mathrm{Su}$ & FI & $\begin{array}{l}\text { Hedges, Datta, Coetzee \& } \\
\text { Dennison (1973) }\end{array}$ \\
\hline ColB-K 98 & + & & FIII & Frydman \& Meynell (1969) \\
\hline $\mathrm{R} 124$ & + & $\mathrm{T}$ & FIV & Hedges \& Datta (1972) \\
\hline R64-1 & - & $\mathrm{A}, \mathrm{S}, \mathrm{T}$, & $1 x$ & Datta et al. (1971) \\
\hline $\mathrm{R}_{46}$ & - & $\mathrm{A}, \mathrm{S}, \mathrm{T}, \mathrm{Su}$ & $N$ & Datta \& Hedges (1971) \\
\hline $\mathrm{R}_{388}$ & - & Su, Tp & W & Datta \& Hedges ( $1972 a$ ) \\
\hline $\mathrm{R}_{48} 8_{3}$ & - & $\mathrm{S}, \mathrm{Tp}$ & $\mathrm{I} \beta$ & Hedges \& Datta (1973) \\
\hline $\mathrm{R} 57 \mathrm{~b}^{*}$ & - & $\mathrm{A}, \mathrm{C}, \mathrm{Gk}, \mathrm{Su}$ & $\mathrm{C}$ & Datta \& Hedges $(1972 b)$ \\
\hline $\mathrm{RP}_{4}$ & - & $\mathrm{A}, \mathrm{T}, \mathrm{K}$ & $\mathbf{P}$ & Datta et al. (197I) \\
\hline R401 & - & $\mathrm{A}, \mathrm{S}$ & $\mathrm{T}$ & Coetzee et al. (1972) \\
\hline $\mathrm{R} 6 \mathrm{~K}$ & - & A, S & $X$ & Hedges et al. (1973) \\
\hline $\mathrm{RA}_{\mathrm{I}}$ & - & $\mathrm{T}, \mathrm{Su}$ & A & Datta \& Hedges (1973) \\
\hline
\end{tabular}

Table 2. Compatibility properties of $J R 70$ and $J R 72$

Abbreviations: K, kanamycin; A, ampicillin; $\mathrm{T}$, tetracycline; pro, proline; his, histidine; trp, tryptophan; met, methionine; " , sensitive; ${ }^{k}$, resistant.

Donor Recipient Selective medium Transfer rate Properties of transconjugants

\begin{tabular}{|c|c|c|c|c|}
\hline J53.2 (JR72) & $\mathrm{J} 62$ & pro, his, trp, $\mathrm{K}$ & $7 \times 10^{-2}$ & $\cos ^{-}$ \\
\hline $\mathrm{J} 53.2(\mathrm{JR} 72)$ & $\mathrm{J} 62(\mathrm{R} I-1)$ & pro, his, trp, $\mathrm{K}$ & $4 \times 10^{2}$ & $18 \mathrm{~A}^{\mathrm{N}} \mathrm{K}^{\mathrm{K}}: 2 \mathrm{~A}^{\mathrm{R}} \mathrm{K}^{\mathrm{r} *}$ \\
\hline $362(\mathrm{R} 1-1)$ & 353 & pro, met, A & $8 \times 10^{-3}$ & $\cdots$ \\
\hline $\mathrm{J} 62\left(\mathrm{R}_{\mathrm{I}}-1\right)$ & J53 (JR72) & pro, met, A & $3 \times 10^{-3}$ & $40 / 40 \mathrm{~A}^{\mathrm{R}} \mathrm{K}^{\mathrm{R}}$ \\
\hline $\mathrm{J} 53.2(\mathrm{JR} 70.1)$ & 362 & pro, his, trp, $T$ & $1 \times 10^{-2}$ & - \\
\hline J53.2(JR70.I) & $\mathrm{J} 62(\mathrm{JR} 72)$ & pro, his, trp, $\mathrm{T}$ & $6 \times 10^{-3}$ & $40 / 40 T^{i} K^{8}$ \\
\hline $\mathrm{J} 62(\mathrm{JR} 72)$ & $\mathrm{J} 53.2$ & pro, met, $\mathrm{K}$ & $1 \times 10^{-1}$ & - \\
\hline $\mathrm{J} 62(\mathrm{JR} 72)$ & $\mathrm{J} 53 \cdot 2(\mathrm{JR} 70 . \mathrm{I})$ & pro, met, $\mathbf{K}$ & $4 \times 10^{-2}$ & $20 / 20 T^{*} K^{n}$ \\
\hline
\end{tabular}

* These were stable and found to carry recombinant R factors with the compatibility properties of $J R 72$ and (at least) the ampicillin resistance gene of $\mathrm{R}_{\mathrm{I}}-1$.

One of these clones was tested and found to be carrying a recombinant plasmid with the resistance markers of both $R_{I-I}$ and $J R_{72}$.

The ability of $J R_{72}$ and $R_{I-I}$ to form recombinants indicates extensive DNA homology between them. Several such recombinants have been observed. One [detected as a transconjugant that retained ampicillin resistance after $J R_{72}$ was transferred to $\left.J 62\left(R_{1}-1\right)\right]$ was studied in greater detail.

This strain was mated with $\mathrm{J} 53(\mathrm{R} / 36)$. When selection was made for transfer of ampicillin or kanamycin resistance into $J 53\left(\mathrm{R}_{136}\right.$ ), in all cases (40 of 40 ) the transconjugants were resistant to ampicillin and kanamycin but sensitive to tetracycline (i.e. R I 36 was eliminated). When RI36 was transferred into the strain carrying the recombinant plasmid, trans- 


\section{Table 3. Incompatibility of segregants of $J R_{72}$}

$J R 72-I$ is a segregant of $J R 72$ which lacks the chlorampenicol-resistance determinant. JR 72-2 is a segregant of JR72 which lacks the kanamycin-resistance determinant. C, Chloroamphenicol; for other abbreviations see Table 2 .

\begin{tabular}{|c|c|c|c|}
\hline Donor & Recipient & Selective medium & $\begin{array}{l}\text { Character of } \\
\text { transconjugants }\end{array}$ \\
\hline $353.2\left(J_{72}-1\right)$ & $\mathrm{J} 62\left(\mathrm{JR}_{72}-2\right)$ & pro, his, trp, $\mathrm{K}$ & $20 / 20 C^{i} K^{1:}$ \\
\hline $\mathrm{J} 62(\mathrm{JR} 72-\mathrm{I})$ & J53.2 (JR72-2) & pro, met, $\mathrm{K}$ & $20 / 20 C^{S} K^{1}$ \\
\hline $\mathrm{J} 53.2(\mathrm{JR} 72-2)$ & $\mathrm{J} 62(\mathrm{JR} 72-1)$ & pro, his, trp, C & $20 / 20 C^{\mathrm{K}} \mathrm{K}^{\mathrm{N}}$ \\
\hline $362(J R 72-2)$ & $\mathrm{J}_{53.2(\mathrm{JR} 72-\mathrm{I})}$ & pro, met, C & ${ }_{19} C^{11} K^{s}: I^{1 i} K^{1 *} *$ \\
\hline
\end{tabular}

* This strain was an unstable double, segregating both $\mathrm{C}^{\mathrm{s}}$ and $\mathrm{K}^{\mathrm{s}}$ progeny.

conjugants all (20 of 20 ) retained ampicillin and kanamycin resistance. Thus, the recombinant plasmid has the compatibility properties of $J R_{72}$ (not $R_{I-I}$, which would have been eliminated by $\mathrm{R}_{\mathrm{I}} 36$ ). This was predictable since the newly formed recombinant plasmid had to be able to compete with JR72 in order to survive.

Transfer of JR72 into cultures carrying representative plasmids of groups Fl (R455), FIII (colB-K98) or FIV (R124) did not eliminate the resident plasmid. Thus, JR72 is not a member of any of these groups.

\section{Compatibility of $J R 72$ and $J R 70$}

Since JR70 seemed intermediate in susceptibility to elimination between JR72 and R1-1 (being eliminable by $\mathrm{R}_{\mathrm{I}-\mathrm{I}}$, but not readily so), we investigated the relationship between JR70 and $J R 72$ by isolating a segregant of the former, JR70-I, which had lost all resistance markers (including fusidic acid resistance) except tetracycline resistance, but was still selftransmissible. In crosses with JR72, JR70-1 behaved precisely as did RI-I (Table 2), i.e. transfer of JR72 eliminated RI-I efficiently, whereas transfer of JR72 into a JR $70-1^{+*}$ strain led to the production of doubles which were stable for $J_{R} 72$ but readily segregated JR $70-1$ clones in the absence of selection for retention of the latter plasmid.

\section{Elimination of segregants of $J R 72$}

A possible explanation of the behaviour of JR72 would be some special barrier to its elimination. To test this possibility, segregants of $\mathrm{JR}_{72}$, one lacking chloramphenicol resistance and the other lacking kanamycin resistance, were isolated. Both segregants retained all testable characters of JR72 other than the single marker. Crosses between strains carrying these segregants (Table 3 ) revealed that elimination of the segregants proceeded with typical efficiency. Thus there was no barrier to the elimination of JR72.

The possibility that $\mathrm{JR}_{72^{-}}$segregants would be inviable in a $\mathrm{JR} 72^{-}$culture (perhaps because the $\mathrm{R}$ factor determined production of, and immunity to, a colicin) was eliminated by reconstruction experiments which showed that growth of an $\mathrm{R}-$ strain was not inhibited by the presence of an excess of $\mathrm{JR}_{72} 2^{+}$cells (nor was production of a colicin by $\mathrm{JR}_{72}+$ cultures demonstrable).

\section{Plasmids conferring no fusidic acid resistance}

Not all F-like plasmids confer fusidic acid resistance, e.g. the segregant JR70-I. Among other FII plasmids tested, RI, R28 and 222 confer resistance to fusidic acid whereas R 136 and R494 do not.

F-like plasmids belonging to compatibility groups other than FII (Flac, R386 and R455 
of group FI, ColB-K98 of group FIII, and RI24 of group FIV) did not affect fusidic acid resistance.

Non-F-like plasmids representing nine compatibility groups were tested for ability to confer fusidic acid resistance; R57b was the only one to show such resistance.

\section{Fusidic acid-resistance $R$ factors in normal strains of Escherichia coli $\mathrm{K} 12$}

By streaking $\mathrm{R}$ and $\mathrm{R} E$. coli strains against ditches containing very high concentrations of fusidic acid it was shown that $\mathrm{R}$ factors which conferred fusidic acid resistance upon the sensitive mutant DBIO also increased the resistance of wild-type strains.

\section{DISCUSSION}

In a variety of Gram-negative and Gram-positive bacteria, mutations to fusidic acid resistance result in an altered protein synthesis component $\left(E F_{G}\right)$ which is normally the binding site for the drug in exerting its inhibitory action on protein synthesis (Davies \& Nomura, 1972). We do not know the mechanism of $\mathrm{R}$ factor-coded fusidic acid resistance. It is unlikely to be an alteration of $\mathrm{EF}_{\mathrm{a}}$ since the resistance level is low. It could be due to altered permeability or enzymic inactivation of the drug.

That certain $\mathrm{R}$ factors should carry a resistance determinant of no apparent use to their normal hosts is of interest, since wild-type Enterobacteriaceae are insensitive to fusidic acid. The resistance is not merely a suppression of the mutant defect, but is expressed in the normal bacterium. One might expect that an apparently useless character would have segregated out during evolution. There are two possible explanations for the presence of this seemingly redundant r-determinant.

(i) Fusidic acid resistance is a gratuitous property associated with another resistance determinant. Resistance to another agent (as yet unknown) may arise by a change which also affects sensitivity to fusidic acid. Perhaps organisms exist which produce steroidal antibiotics whose actions resemble fusidic acid (so that a bacterium may increase its resistance to all such molecules by a single mechanism) and which are active against Gram-negative bacteria at concentrations attainable in nature. The fusidic acid resistance may have evolved as a response to these antibiotics.

(ii) $\mathrm{R}$ factors are very stable and can keep their r-determinants even in the absence of selection (e.g. many $R$ factors still carry streptomycin resistance, although streptomycin is not much used in medicine). We therefore suggest that $\mathrm{R}$ factors and staphylococcal plasmids are genetically related (they possess several common resistance determinants, in addition to fusidic acid). Perhaps an exchange mechanism exists whereby plasmids, or parts of plasmids, may be exchanged between Gram-positive and Gram-negative strains. Both E. coli and S. aureus are susceptible to transfection by plasmid DNAs (Cohen, Chang \& Hsu, 1972; Lindberg, Sjöström \& Johansson, 1972) so that genetic exchange need not involve conjugation between cells but merely the uptake of free DNA molecules by the recipient.

Whatever their origins, the fusidic acid-resistance factors are transmissible $\mathrm{R}$ factors in E. coli. R factor $\mathrm{R} 57 \mathrm{~b}$, a protype of compatibility group $\mathrm{C}$ (Datta \& Hedges, $1972 b$ ) was the only fi plasmid shown to determine fusidic acid resistance. The others were all $\mathrm{fi}$ and related to compatibility group FII. Some, e.g. R I, are typical members of the group, eliminating and being eliminated by other plasmids of the group, but others are unusually resistant to elimination by members of the group. However, they show other characteristics of group FIl, efficiently eliminating or undergoing recombination with resident FII plasmids. Their 
compatibility properties resemble those of the mutant R I plasmids described by Nordström, Ingram \& Lundbäck (1972).

We thank Dr W. O. Godtfredsen of Leo Pharmaceuticals for generous gifts of fusidic acid. This work was supported by the National Institutes of Health.

\section{REFERENCES}

Coetzee, J. N., Datta, N. \& Hedges, R. W. (1972). R factors from Proteus rettgeri. Journal of General Microbiology 72, 543-552.

Cohen, S. N., Chang, A. C. Y. \& Hsu, L. (1972). Nonchromosomal antibiotic resistance in bacteria : genetic transformation of Escherichia coli by R factor DNA. Proceedings of the National Academy of Sciences of the United States of America 69, $2110-2114$.

Cundliffe, E. (1972). Antibiotic inhibitors of ribosome functions. In Molecular Basis of Antibiotic Action, p. 278. Edited by E. F. Gale, E. Cundliffe, P. E. Reynolds, M. H. Richmond and M. J. Waring. New York: Wiley Interscience.

Datta, N. \& Hedges, R. W. (197I). Compatibility groups among $f^{-}$R factors. Nature, London 234, 222-223.

DAtTA, N. \& Hedges, R. W. (1972 $a$ ). Trimethoprim resistance conferred by W plasmids in Enterobacteriaceae. Journal of General Microbiology 72, 349-356.

Datta, N. \& Hedges, R. W. (1972 b). R factors identified in Paris, some conferring gentamicin resistance, constitute a new compatibility group. Annales de l'Institut Pasteur I23, 879-882.

Datta, N. \& Hedges, R. W. (1973). R factors of compatibility group A. Journal of General Microbiology 74, $335-336$.

Datta, N., Hedges, R. W., Shaw, E., Sykes, R. B. \& Richmond, M. H. (1971). Properties of an R factor from Pseudomonas aeruginosa. Journal of Bacteriology 108, I 244-1249.

Davies, J. \& Nomura, M. ( (1972). The genetics of bacterial ribosomes. Annual Review of Genetics 6, 203-234.

Dennison, S. (1972). Naturally occurring R factor, depressed for pilus synthesis, belonging to the same compatibility group as the sex factor F of Escherichia coli KI2. Journal of Bacteriology 109, 416-422.

ENNIS, H. L. (197I). Mutants of Escherichia coli sensitive to antibiotics. Journal of Bacteriology 107, 486-490.

EVANS, R. J. \& WATERWORTH, P. M. (1966). Naturally occurring fusidic acid resistance in Staphylococci and its linkage to other resistances. Journal of Clinical Pathology 19, 555-560.

Frydman, A. \& Meynell, E. (I969). Interactions between de-repressed F-like R factors and wild type colicin B factors: superinfection immunity and represser susceptibility. Genetical Research 14, 31 5-332.

Garrod, L. P., Lambert, H. P. \& O'Grady, F. (I973). Antibiotics and Chemotherapy, 4th edn. Edinburgh and London: Churchill Livingstone.

Hedges, R. W. \& DatTA, N. (1972). Rı24, an $f^{\dagger}$ R factor of a new compatibility class. Journal of General Microbiology 7r, 403-405.

Hedges, R. W. \& Datta, N. (1973). Plasmids determining I pili constitute a compatibility complex. Journal of General Microbiology 77, 19-25.

Hedges, R. W., Datta, N., Coetzee, J. N. \& Dennison, S. (1973). R factors from Proteus morganii. Journal of General Microbiology 77, 249-259.

Lawn, A. M., Meynell, E., Meynell, C. G. \& Datta, N. (1967). Sex pili and the classification of sex factors in the Enterobacteriaceae. Nature, London 216, 343-346.

LindBerg, M., SJöström, J. E. \& JohansSon, T. (1972). Transformation of chromosomal and plasmid characters in Staphylococcus aureus. Journal of Bacteriology 109, 844-847.

MacFarren, A. C. \& Clowes, R. C. (1967). A comparative study of two F-like colicin factors, ColV 2 and $\mathrm{ColV}_{3}$ in Escherichia coli. Journal of Bacteriology 94, 365-377.

Nordström, K., IngRAm, L. C. \& LundBäcK, A. (1972). Mutations in R factors in Escherichia coli causing an increased number of R factor copies per chromosome. Journal of Bacteriology 110, 562-569.

PestKa, S. (1971). Inhibitors of ribosome functions. Annual Review of Microbiology 25, 487-562.

TAYLor, A. L. (1970). Current linkage map of Escherichia coli. Bacteriological Reviews 34, 155-175.

Watanabe, T., Nishida, H., Ogata, C., Arai, T. \& Sato, S. (I964). Episome mediated transfer of drug resistance in Enterobacteriaceae. VII. Two types of naturally occurring R factors. Journal of Bacteriology 88, 7 I $6-726$. 